\title{
The Place of Anzac in Australian Historical Consciousness ANNA CLARK
}

There is an ever-greater popular attachment to the commemoration of Anzac Day in Australia, with growing commercial, popular and institutional support around the country. This resurgence has also generated significant disagreement among historians, shaping the historiography of Anzac in recent years and raising important questions about Australia's current obsession with Anzac: is it a reflection of increasing popular historical engagement, or an ideologically driven 'mobilisation' of the past? While various scholars have sought to unpack and understand this potent phenomenon of national sentiment, this article, based on a series of oral interviews with ordinary Australians in selected communities, reveals an uncertainty and complexity in many vernacular responses to Anzac that need to be included if that commemorative sentiment is to be properly understood.

What about a day like Anzac Day-does that mean anything to you?

Jed: A lot, like a lot. It's, like, more than Australia Day.

Why is that?

Jed: It's like special because people died for us, and that's why we're so free now.

Jed, 13, Willoughby Youth Action Group, Chatswood ${ }^{1}$

Anzac Day is invested with ever-greater popular attachment in Australia, as the huge crowds on 25 April attest. In 1984 an estimated 50,000 people attended Anzac Day marches around the nation; a generation later, in 2014, more than that number alone attended the Dawn Service at Melbourne's Shrine of Remembrance. ${ }^{2}$ In that same

My thanks to Leigh Boucher, Alecia Simmonds and Clare Wright for reading various drafts of this article.

${ }^{1}$ Interview with Willoughby Youth Action Group, Chatswood, 19 May 2009. (The names of all participants have been changed.)

${ }^{2}$ Graeme Davison, 'The Habit of Commemoration and the Revival of Anzac Day', Australian Cultural History, no. 22 (2003): 73-82; Australian Broadcasting Corporation, 'Anzac Day 2014: Thousands attend services worldwide to commemorate Anzac Day’, 25 April 2014,

http://www.abc.net.au/news/2014-04-25/thousands-attend-services-worldwide-to-commemorate-anzacday/5411304 (accessed 26 April 2014). See also Marilyn Lake, Henry Reynolds, Mark McKenna and 
year, the commemorative 'festival', which accompanied Anzac Day, also included the Australian War Memorial's national collection of messages of gratitude to fallen diggers from school children (to be placed on every overseas Australian war grave). Meanwhile, newspaper advertisements enticed readers to 'order' a minute's silence to their mobile phones on Anzac Day (for a mere \$2.25). ${ }^{3}$

Several historians have pondered this extraordinary Anzac resurgence over the last three decades. ${ }^{4}$ Graeme Davison suggests that Anzac Day fills a vacuum of social ritual in contemporary Australian life, particularly as it has become more secular. ${ }^{5}$ Carolyn Holbrook further argues that the publication of popular social histories of Australians at war from the late 1960s coincided with increasing interest in family and

Joy Damousi, What's Wrong With Anzac? The Militarisation of Australian History (Sydney: New South, 2010); Mark Brissenden, 'Should Anzac Day inspire more than just fervour?', ABC The Drum, 25 April 2013, http://www.abc.net.au/news/2013-04-25/brissenden-should-anzac-day-inspire-morethan-just-fervour/4651370 (accessed 29 April 2013); Paul Daly, 'Anzac Day: duck as the glory talk flies', The Guardian, 25 April 2014, http://www.theguardian.com/news/postcolonial/2014/apr/24/anzac-day-time-to-duck-as-guts-andglory-assault-the-senses (accessed 4 June 2014). Significant numbers of Australian backpackers and tourists also take the rite of passage to Anzac Cove and other sites of national military history: Kevin Blackburn, 'Changi: A Place of Personal Pilgrimages and Collective Histories', Australian Historical Studies 29, no. 112 (1999): 152-71; Bruce Scates, 'Walking with History: School Excursions to the Cemeteries of the Great War', in A Future for the Past: The State of Children's History, ed. Bruce Scates (Sydney: History Council of New South Wales, 2004), 93-118; Bruce Scates, Return to Gallipoli: Walking the Battlefields of the Great War (New York: Cambridge University Press, 2006); Romain Fathi, 'Connecting Spirits: The commemorative patterns of an Australian school group in Northern France', Journal of Australian Studies 38, no. 3 (2014): 345-59.

${ }^{3}$ Mervyn Bendle, 'The Military Historians' War on the Anzac Legend', Quadrant, 29 March 2014, http://quadrant.org.au/magazine/2014/04/military-historians-war-anzac-legend/ (accessed 19 June 2014); James Brown, Anzac's Long Shadow (Melbourne: Black Inc., 2014); Australian Broadcasting Corporation, 'Students send messages of thanks to fallen soldiers', ABC News Canberra, 23 April 2014, http://www.abc.net.au/news/2014-04-23/students-send-messages-of-thanks-to-fallensoldiers/5407640 (accessed 25 April 2014); Returned Services League, 'Minute of Silence', 2014, www.minuteofsilence.com.au (accessed 20 April 2014).

${ }^{4}$ While not wanting to conflate this resurgent Anzac commemoration with the actual military performance of the ANZAC forces at Gallipoli in the First World War, this article refers to 'Anzac' as 'shorthand for intense interest in Australia's war heritage and the public expression and commemoration of it', from Christina Twomey, 'Trauma and the reinvigoration of Anzac: An argument', History Australia 10, no.3 (2013): 87.

${ }^{5}$ Davison, 73-82. 
community history, a familial 'memory boom', and contributed to growing quotidian claims on the national narrative. ${ }^{6}$ Meanwhile, Christina Twomey contends that changing understandings of trauma have also influenced the popular memorialisation of Anzac in recent decades. Narratives of victimhood have increasingly shaped Anzac memory, she suggests, where 'the suffering of veterans, their psychological fragility and the horrors they have witnessed that provide an important, if not an exclusive, framing device' for the memory of Anzac. ${ }^{7}$

One particular debate has captured the historiographical imagination of Anzac in recent years, however. In pondering the spectre of Anzac pilgrimage to Gallipoli and the Western Front in this journal in 2002, historian Bruce Scates described the growing 'rite of passage for both young and old Australians' as a 'journey to a sacred place', which involved 'an emotional ordeal that led ultimately to personal enrichment'. ${ }^{8}$ These historical tourists-mostly young backpackers-displayed a 'search for transcendence' and 'wanderlust', and reflected a nostalgic 'resurgence of national identity', Scates later wrote. ${ }^{9}$ At a time when politicians, historians and educationists bemoan the historical engagement of 'ordinary Australians', particularly young people, here is a cohort actively feeling and expressing an intense historical connection through the figure of Anzac. ${ }^{10}$

This commemorative cohort confirms the 'sense of living connection' people make and maintain with their histories, as historian Marianne Hirsch has observed in relation to inter-generational memory. 'Memory signals an affective link to the past,'

\footnotetext{
${ }^{6}$ Carolyn Holbrook, Anzac: The Unauthorised Biography (Sydney: New South, 2014); see also Joan Beaumont, 'Remembering the Heroes of Australia's Wars', in Heroism and the Changing Character of War, ed. S. Scheipers (Basingstoke: Palgrave Macmillan, 2014), 338.

7 Twomey, 'Trauma and the reinvigoration of Anzac', 85-108. See also Christina Twomey, 'Anzac Day: are we in danger of compassion fatigue?', The Conversation, 24 April 2014, http://theconversation.com/anzac-day-are-we-in-danger-of-compassion-fatigue-24735 (accessed 28 May 2014).

${ }^{8}$ Bruce Scates, 'In Gallipoli’s Shadow: Pilgrimage, Memory, Mourning and the Great War', Australian Historical Studies 33, no. 119 (2002): 2.

${ }^{9}$ Bruce Scates, Return to Gallipoli.

${ }^{10}$ Anna Clark, Teaching the Nation: Politics and Pedagogy in Australian History (Melbourne: Melbourne University Press, 2006); Kevin Donnelly, Dumbing Down (Melbourne: Hardie Grant Books, 2007); Anna Clark, History's Children: History Wars in the Classroom (Sydney: New South, 2008).
} 
she contends, 'a sense precisely of an embodied "living connection". ${ }^{11}$ Yet that cohort also reveals the social and political context of 'emotional communities', Barbara Rosenweig reminds us, where emotions are constituted by, and in turn shape, the performance of collective memory in public life. ${ }^{12}$

Indeed, historians Mark McKenna and Stuart Ward argued that the Anzac phenomenon Scates identified has 'less and less to do with "history", and more and more to do with the commerce and politics of nationalism'. ${ }^{13}$ They wondered to what extent "that "hunger for meaning" and "craving for ritual" [Scates] found in the Gallipoli pilgrims is manufactured by the prevailing political and commercial imperatives in contemporary Australia?' 14 Marilyn Lake, Joy Damousi, Peter Stanley and Henry Reynolds have similarly pondered the effects of such a historical 'mobilisation', including the advancement of substantial public funding-by successive governments and their departments, public institutions, and even school curricula - on fostering collective attachment to Australia's military past. ${ }^{15}$ This occurs simultaneously to the active forgetting of Australia's violent and long frontiers

\footnotetext{
${ }^{11}$ Marianne Hirsch, 'The Generation of Postmemory', Poetics Today 29, no. 1 (2008): 111.

${ }^{12}$ Barbara Rosenwein, 'Worrying About Emotions in History', American Historical Review 107, no. 3 (2002): 821-45. See also Sara Ahmed, The Cultural Politics of Emotion (Edinburgh:
}

Edinburgh University Press, 2004), 4, who writes about 'the sociality of emotion'; Sarah Pinto, 'Emotional Histories and Historical Emotions: Looking at the Past in Historical Novels', Rethinking History 14, no. 2-3 (2010): 189-207; Robert Dixon, 'Citizens and Asylum Seekers: Emotional Literacy, Rhetorical Leadership and Human Rights', Cultural Studies Review 8, no. 2 (2002): 11-26; and Fay Bound, 'Writing the Self? Love and the Letter in England, c. 1660-c. 1760', Literature and History 1, no. 11 (2002): 1-19.

${ }^{13}$ Mark McKenna, and Stuart Ward, “It was really moving, mate": The Gallipoli Pilgrimage and Sentimental Nationalism in Australia', Australian Historical Studies 38, no. 129 (2008): 144. See also Mark McKenna, 'Patriot act', The Australian (Australian Literary Review), 6 June 2007, 1, 3, 14 : 'Australians appear to have lost the ability (or inclination) to debate Anzac Day', he writes. 'It has become an article of national faith and communion, a sacred parable we dare not question, yet another indication of the narrowing of political debate in Australia.'

${ }^{14}$ McKenna and Ward, 151.

${ }^{15}$ Lyn Spillman, 'When Do Collective Memories Last? Founding Moments in the United States and Australia', in States of Memory: Continuities, Conflicts, and Transformations in National Retrospection, ed. Jeffrey K. Olick (Durham: Duke University Press, 2003), 162-3; Lake et al, What's Wrong With Anzac?; Peter Stanley, 'Do teachers have "patriotic" obligations?' ACT-NSW History Teachers' Associations conference, University of Canberra, 9 May 2014, http://honesthistory.net.au/wp/stanley-peter-patriotic-teachers/ (accessed 3 July 2014). 
wars fought by Europeans against Aboriginal Australians, until recently an obscured aspect of Australia's military history. Australia's frontier wars remain a forgotten vestige of the Anzac legacy, as Reynolds points out. ${ }^{16}$

This debate has shaped historiography of the Anzac resurgence in recent years, as each side seeks to unpack and understand that commemorative phenomenon. ${ }^{17}$ Yet significant questions about the historical revival remain unanswered: does this potent, popular and affective Anzac reverence mean the same thing to all its adherents, for example? Is the Anzac legacy a genuinely unifying 'national moment' for those who observe it? In response, this article reports on a study that ventured into neighbourhood centres, community kitchenettes and tea rooms around Australia to ask precisely that question: what does Anzac Day mean to you? In doing so the study uncovered significant popular exceptions, which challenge the ubiquity of Anzac's contemporary appeal.

\section{Investigating historical consciousness}

This exploration of the popular Anzac resurgence forms part of a larger qualitative study of historical consciousness in Australia. Employing what Adele Clarke calls a 'situational analysis', Private Lives, Public History maps historical engagement of socalled 'ordinary people' alongside public discourses of the past, contemplating themes of historical connectedness and inheritance, as well as commemoration, contestation and place. ${ }^{18}$ Paradoxically, while ordinary people are constantly co-opted into wider historical debates, little is known about how they articulate their own historical consciousness in the context of powerful national narratives such as Anzac. The difficulty of understanding everyday historical consciousness does not diminish its importance, however: German historical theorist Jörn Rüsen has insisted on examining what he describes as the 'most profane procedures of memory'; Finnish

\footnotetext{
${ }^{16}$ Henry Reynolds, Forgotten War (Sydney: New South, 2013).

${ }^{17}$ Michelle Arrow, “I Just Feel it's Important to Know Exactly What He Went Through”: In Their Footsteps and Australian Television History', Historical Journal of Film, Radio and Television 33, no. 4 (2013): 599.

${ }^{18}$ Adele Clarke, Situational Analysis: Grounded Theory After the Postmodern Turn (Thousand Oaks, CA: Sage Publications, 2006); the Private Lives, Public History, project was undertaken by the author as part of a Chancellor's Postdoctoral Fellowship at the University of Technology Sydney.
} 
scholar, Sirkka Ahonen, has similarly argued that contemplating the 'vernacular level of social memory' is a critical element of understanding historical consciousness. ${ }^{19}$

The research presented in this article likewise insists on navigating everyday historical consciousness in order to understand the place and role of history in Australian society. The research employs a new method that could best be described as 'oral historiography' to examine popular engagement with national historical debates: it uses qualitative research techniques of oral history and focus group work, along with critical analysis of public debates, to examine how people negotiate family and community histories as well as national narratives, and why. ${ }^{20} \mathrm{In}$ short, the research seeks to understand historical consciousness as a product of both intimate and public historical contexts.

Five communities were chosen to conduct this Australian study using a purposive sampling method as a way to generate a breadth of socio-economic, cultural and geographic background among participants. ${ }^{21}$ The five communities chosen were Marrickville (a multicultural municipality in inner Sydney), Chatswood (a community in Sydney's affluent North Shore), Brimbank (a multicultural and working class community in outer western Melbourne), Rockhampton (a large rural town in central Queensland), and Derby (a remote town with a large Indigenous population in far north-western Australia). Using this qualitative research method enables particular participants and communities to be deliberately approached: this was not to be a random or demographically representative sample of the Australian population, but a targeted collection of participants — one hundred in total—who came

\footnotetext{
${ }^{19}$ Jörn Rüsen, 'Preface', in Narrative Identity, and Historical Consciousness, ed. Jörgen Straub (New York: Berghahn Books, 2005), vii-xii; Sirkka Ahonen, Coming to Terms with a Dark Past: How PostConflict Societies Deal with History (Frankfurt: Peter Lang, 2012), 13. See also Sam Wineburg, Historical Thinking and Other Unnatural Acts: Charting the Future of Teaching the Past (Philadelphia: Temple University Press, 2001), 249, and David Glassberg, Sense of History: The Place of the Past in American Life (Amherst: University of Massachusetts Press, 2001), 16, for discussion about the lack of scholarship into everyday historical consciousness.

${ }^{20}$ I have found reference to 'oral historiography' only once in any widely cited work - by David Henige, in his survey of the varied practices of oral history: David Henige, Oral Historiography (London: Longman 1982).

${ }^{21}$ For an explanation and example of purposive sampling, see: Tim Phillips and Philip Smith, 'What is "Australian"? Knowledge and Attitudes Among a Gallery of Contemporary Australians', Australian Journal of Political Science 35, no. 2 (2000): 206-7.
} 
from different generations, schooling, ethnic background and class, and represented a diversity of voices and experiences.

Participants were approached through extant 'affinity groups'-community organisations such as seniors' centres and sporting clubs, education institutions such as universities and TAFEs, as well as migrant resource centres, youth groups and so on. ${ }^{22}$ The average age of the participants was forty-nine, twelve years above the Australian average. This can probably be explained by two factors. First, according to the Australian Bureau of Statistics, Australians are more involved in community groups and volunteering in middle age and following retirement, so that demographic was likely to be over-represented in the community groups I visited. Second, people tend to become more interested in history as they get older, and this was certainly confirmed in my research. ${ }^{23}$ In order to minimise that anticipated generational skew, I organised interviews with two youth groups from Chatswood and Brimbank, as well as students from two university classes in Rockhampton and Brimbank.

There was also a significant gender bias among my participants. Only thirtythree men took part in this project (twenty-six per cent below the population average). While significant numbers of both men and women participate in volunteering and community engagement in Australia, women tend to be more active in the production of family and community histories. ${ }^{24}$ To counteract the gender discrepancy that was increasingly apparent as the interviews progressed, I arranged to speak with a group

${ }^{22}$ For a discussion of using affinity groups in qualitative research, see Hugh Mackay \& Randall Pearce, The Mackay Report: Mind and Mood 2003 (Sydney: Ipsos Mackay, 2003), 4.

${ }^{23}$ Australian Bureau of Statistics, http://www.abs.gov.au/ausstats/abs@.nsf/Products/A28A88030FCD650ACA25791A0082C4A9?open document (accessed 5 April 2015); Paul Ashton and Paula Hamilton, History at the Crossroads: Australians and the Past (Sydney: Halstead Press, 2010), 29; Margaret Conrad et al., Canadians and Their Pasts (Toronto: University fo Toronto Press, 2013); Roy Rosenzweig and David Thelen, The Presence of the Past: Popular Uses of History in American Life (New York: Columbia University Press, 1998), 43-4.

${ }^{24}$ Australian Bureau of Statistics: http://www.abs.gov.au/ausstats/abs@.nsf/Products/70673659385DC4E3CA25791A0082C494?opendo cument, (accessed 5 April 2015); and http://www.abs.gov.au/ausstats/abs@.nsf/Products/A28A88030FCD650ACA25791A0082C4A9?open document, (accessed 5 April 2015); Conrad et al., 41-42; Rosenzweig and Thelen, 28-30; Peter Read, “"Before Rockets and Aeroplanes": Family History', Australian Cultural History, no. 22 (2003): 13233. 
from a men's shed in Chatswood and made sure I conducted one-on-one male interviews in each of the five communities.

Aboriginal and Torres Strait Islander people were over-represented in these interviews, making up ten per cent of all participants. This bias was deliberate: while public historical debates have been significantly weighted to Indigenous issues, Indigenous voices have been notably absent from them. As such, I was eager to discern particular themes of Indigenous historical consciousness that might operate despite that national vacuum. Migrants made up about twenty-five per cent of the participants, reflecting population ratios in the broader community, and they contributed fascinating discussions about the complexity of history and identity, for example, in relation to ideas of home, inheritance and nation. ${ }^{25}$

Unlike several larger, mixed-methods studies of historical consciousness, the shape and size of this project was necessarily limited by its focus on non-directive, community-based research, where I would essentially be 'listening in' on people's conversations-conversations that were critical to exploring intersections between community and public historical discourses. Such a grounded approach, across five very different communities with a wide range of participants, would inevitably reflect a diversity of voices and historical perspectives. As such, the research reveals considerable breadth in the ways Australians relate to the Anzac commemoration.

Comments from Indigenous and migrant respondents, in particular, hint at the multi-valency of Anzac remembrance, commemoration and counter-commemoration. Yet cultural diversity is not the only predicator of historical engagement: within the same community groups, respondents frequently presented vastly different interpretations of Anzac. Taken together, their conversations confirm the resilience of Anzac noted recently by Joan Beaumont - this is a national emblem that has endured and adapted for one hundred years, after all. ${ }^{26}$ They also suggest that Anzac memory is far from settled in Australians' historical consciousness: despite its significance in national collective memory, the community conversations recorded for this project reveal considerable disagreement and debate about its meaning on the ground. It

\footnotetext{
${ }^{25}$ Department of Immigration and Border Protection, http://www.immi.gov.au/media/statistics/historical-migration-stats.htm, (accessed 12 November 2014): http://www.abs.gov.au/ausstats/abs@.nsf/mf/3412.0 (accessed 22 September 2016)

${ }^{26}$ Beaumont, 334.
} 
seems the Anzac legacy has generated a commemorative space more complex and uncertain than public and official demonstrations of Anzac pride suggest.

\section{Beginning to unpack Anzac's popularity}

These interviews confirm the commemoration of Australia's Anzac history is both a public and popular phenomenon deeply felt by many Australians. Young Jed from Chatswood was far from alone among the respondents in his unfettered adulation of the Anzac legacy. Jarrod, a Rockhampton university student in his twenties, similarly felt Anzac day was important, because 'a lot of people lost their lives. And when you think about it - your life is — there's nothing more', he said. 'They've lost everything for us here, so we've got to think about that. I think that's important'. ${ }^{27}$ At a university class in Brimbank, Anzac Day made Tony 'just feel proud and stuff'. ${ }^{28}$

The interviews suggest a generational bias to that resurgence, since younger respondents (aged 13-30) more often exhibited an abiding, uncritical fealty with Australia's Anzac legacy than their older counterparts. That youthful interest in and engagement with Anzac history is confirmed by studies of schoolchildren, who, with the exception of Anzac topics, generally loathe learning Australian history. ${ }^{29}$ It also reinforces charges from teachers and historians that public spending on teaching resources from government departments, such as the Department of Veterans Affairs, has been heavily weighted to Australia's military history in recent years. ${ }^{30}$

For a number of those respondents, the historical connection forged around Anzac was deeply personal. Colin (89 years), spoke at the Chatswood Men's Shed, and was a veteran of the First World War. 'My father fought in the first war, and the second war, and I fought in the second war', he explained, before describing his enjoyment of Anzac Day: 'There's the camaraderie, seeing those people you haven't seen since the year before'. ${ }^{31}$ Speaking to the Brimbank university class, Silvie described how her father had fought in the Vietnam War and her grandfathers served in the Second World War. Anzac Day therefore had 'a strong personal connection' for

\footnotetext{
${ }^{27}$ Interview with Jarrod, university, Rockhampton, 28 May 2009.

${ }^{28}$ Interview with university group, Brimbank, 18 May 2009.

${ }^{29}$ Clark, History's Children, 44-48.

${ }^{30}$ Ibid., 48-9; Lake et al., What's Wrong With Anzac?, 147-56.

${ }^{31}$ Interview with Men's Shed, Chatswood, 14 October 2010.
} 
her, and attending the ceremony was something she did 'on an annual basis to pay respect'. 32

Adam, from a Brimbank youth centre, similarly described how personal connections to Australia's military history naturally meant it acquired greater meaning: 'a lot of our grandparents and great-uncles and things like that sort of have more of a connection with more recent wars, rather than Australia being discovered and things like that'. ${ }^{33}$ Was Anzac Day an occasion that young people tend to connect with more or less than other national days? I asked Liu (24 years), from Derby, who has Chinese heritage,

I think more young people connect to this public holiday more than any other, because of the fact that a lot of young people can trace themselves back to Anzacs here in Australia. Or they've got family that's in the military and stuff. So that's, I think, a way to relate. But yeah, I think it's probably the most important of all public holidays for young people. ${ }^{34}$

Their comments confirm broader results from the qualitative study, which reveal that moments of historical connection and inheritance are overwhelmingly personal. And they tend to occur when people can situate themselves and their own family or community stories within or alongside the public, national narrative in question. ${ }^{35}$ In other words, people's engagement with the Australian story is framed by personal experience, rather than the overt presence of an innate, official, and abstract national history-hence the ancestral allure of Anzac.

The responses collected in this study are also suggestive of the reiterative nature of commemoration, which is bound as much by the present as much as it is an effect of the past. When Graham (61 years) in Marrickville explained why he took part in the Dawn Service at Sydney's Martin Place every year, he became almost lost for words: 'It means something to me', he eventually managed to say, with a current emphasis. Others talked about the emotional 'twinge' they felt annually on that day, as Tony, a retiree, from the Chatswood Bushcare Group described it, or about how important it was to 'reflect on that suffering', as Amelia (70 years) explained, for just

\footnotetext{
${ }^{32}$ Interview with university group, Brimbank, 18 May 2009.

${ }^{33}$ Interview with youth centre, Brimbank, 19 May 2009.

${ }^{34}$ Interview with Community Radio Station, Derby, 8 August 2011.

${ }^{35}$ Anna Clark, 'Ordinary People’s History', History Australia 9, no. 1 (2012), 206; Anna Clark,

'Inheriting the past: Exploring historical consciousness across the generations', Historical Encounters 1, no. 1 (2014): 88-102.
} 
'one day a year'. ${ }^{36}$ These participant comments confirm historian and cultural theorist Jay Winter's observation that commemorations are constantly re-enacting and reiterating the past as contemporary forms. ${ }^{37}$ 'They are all in time', Greg Dening argued in his influential ethnographic reading of Anzac Day. 'They cannot be set in stone or gold'. 38

Significantly, that affective presentness of Anzac in the interviews not only confirms the personal dimension of its contemporary resurgence, but also helps explain the complexity and modulation of Anzac Day in Australians' historical consciousness. Public commemorations such as Anzac Day are a collision of collective and personal memory, as Scates suggests, where these participants' experiences coalesce around broader public historical narratives. ${ }^{39}$ Yet that emotional connection is at the heart of its very subjectivity: as historian Michelle Arrow insists, 'While emotion is a powerful point of entry to the past, it is also a volatile and unstable one, with the potential to produce a broader array of interpretations than mere pride or shame'. ${ }^{40}$ Despite the central place of Anzac in public memory, that centrality belies a commemorative fluidity also operating in Australian communities.

\section{Indigenous commemoration}

In their interviews, Indigenous respondents echoed the significance of Anzac Day as a point of connection to the past. Like a number of non-Indigenous participants, several had personal links that informed their historical interest and engagement. Some, like Trevor (60 years) from Derby, had served in the armed forces:

\footnotetext{
${ }^{36}$ Interview with Chatswood Bushcare Group, 28 October 2010.

${ }^{37}$ Jay Winter, 'The Performance of the Past: Memory, History, Identity', in Performing the Past: Memory, History and Identity in Modern Europe, eds Karin Tilmans, Frank van Vree and J. M. Winter (Amsterdam: Amsterdam University Press, 2010), 11-23. See also Peter Burke, 'History as Social Memory', in Memory: History, Culture and the Mind, ed. Thomas Butler (Oxford: Basil Blackwell, 1989), 97-113; Barbara Tint, 'History, Memory, and Intractable Conflict', Conflict Resolution Quarterly 27, no. 3 (2010): 239-56.

${ }^{38}$ Greg Dening, 'ANZAC Day: An Ethnographic Reflection after Reading Bruce Kapferer', Social Analysis: The International Journal of Social and Cultural Practice, no. 29 (1990): 62-66.

${ }^{39}$ Scates, Return to Gallipoli, 214.

40 Arrow, 597.
} 
I did serve in the National Service... so it has got a significance to me. And I've found that ever since I've been involved with Anzac... I've never missed an Anzac Day since '72. And I still march. I don't wear my uniform, but I wear my medals to the Dawn Service' ${ }^{41}$

Karla, an Indigenous teacher from Derby in her 30s also had a personal connection to Anzac. Does Anzac Day speak more to Aboriginal people than Australia Day? I asked. She replied,

I think so, yeah. For me personally, my father was in the Second World War, and I just think that's something that needs to be celebrated. I mean, my husband's uncle, he was a prisoner of war and he celebrated Anzac Day every year. He marched and wore his medals. So, yeah. ${ }^{42}$

Critically, that remembrance of the dead was framed in an Indigenous cultural narrative of remembrance. 'I believe that Anzac Day is a day for respecting', said Jenny (58 years), an elder from an Aboriginal women's centre in Derby:

We have to respect people that fought for this country, you know, regardless what colour. I always respected Anzac Day, in school, being part of all that ceremony, you know, as school kids. And I mean, who cannot respect Anzac Day, you know, regardless what colour you are, you know. Where would Australia be today? ${ }^{43}$

On the surface, Jenny's comments seemingly confirm the Anzac resurgence as a reflection of Australian pride — where 'would Australia be today?', she asks. Yet they also hint at an Indigenous sensibility about dying for country, something with which Kimberley Aboriginal people are all too familiar. And as the following discussion between Jenny and Violet about Australia Day reveals, reading Indigenous respect for the Anzacs simply as a mark of national sentiment would be superficial and problematic:

How do you feel on a day like Australia Day?

Violet: What do you mean, like Australia born?

Jenny: When people came.

Violet: No.

Jenny: That's when them first settlers came across eh? In the past, it didn't worry me, it's like one more holiday, but now I'm learning what it really means. It means, like, white settlers come to Australia and, um,

Violet: Took over.

\footnotetext{
${ }^{41}$ Interview with Community Radio Station, Derby, 8 August 2011.

${ }^{42}$ Interview with Indigenous primary teachers, Derby, 8 August 2011.

${ }^{43}$ Interview with Indigenous Women's Centre, Derby, 8 August 2011.
} 
Jenny: Yes. I believe maybe we should have another day for Aboriginal people, have a holiday on another day, you know, just nationally, for everyone.

Violet: That's what I say. It doesn't mean a holiday to us, because it's a day Europeans come and take over the country, you know. ${ }^{4}$

Jenny and Violet's critical reading of Australia Day indicates their commitment to and belief in Anzac commemoration does not equate to a commitment or belief in Australian history or national identity.

Other Indigenous participants also distinguished their commemoration of Anzac Day from any sense of Australian nationalism. Is it a day that speaks more to Aboriginal people than Australia Day? I asked a group of Indigenous teachers and teachers aides in Derby: 'I think so, yeah', answered Karla. ${ }^{45}$ For Tani (36 years) in Marrickville, Anzac Day represented a sort of alternate commemoration, since she and her family avoided the official Dawn Service and parade in favour of an Indigenous community event:

So on Anzac Day, my family, we actually go to a parade which is run just by the Indigenous community - do you know it? It's in Redfern, and they go there so they can voice, so it's a separate thing compared to the mainstream [one] which occurs early in the morning. This parade takes place at about lunchtime and it starts at the Block (...) But as I said, a lot of Aboriginal soldiers have served during the time, and it is a day of great importance for Aboriginal people because they have contributed to Australian history in a huge way. ${ }^{46}$

That Indigenous reluctance to identify Anzac with a broader national sentiment complicates broader understandings of the Anzac resurgence: it suggests a commemorative subjectivity that at once reinforces and questions Anzac's place in Australian collective memory. It also reveals the importance of Indigenous family histories that sustain intimate family connections to the past, as historians Maria Nugent and Fabri Blacklock note, as well as represent a critical, alternative voice- $\mathrm{a}$ counter narrative - to Australia's national collective memory. ${ }^{47}$

\section{The multicultural dimension of Anzac}

\footnotetext{
${ }^{44}$ Interview with Indigenous Women's Centre, Derby, 9 August 2011.

${ }^{45}$ Interview with Indigenous primary teachers, Derby, 8 August 2011.

${ }^{46}$ Interview with Tani, Marrickville, 3 December 2011.

${ }^{47}$ Fabri Blacklock, 'Telling it our Way: Koori History in NSW', Australian Cultural History, no. 22 (2003): 155-60; Maria Nugent, 'Aboriginal Family History: Some Reflections', Australian Cultural History, no. 22 (2003): 143-53.
} 
While the Private Lives, Public History project confirms how family and community experience shape historical engagement, its flipside - historical disconnectedness - is much harder to map. Finding people who do not connect to Anzac Day is tricky when so much qualitative research depends on self-selecting participants, or records of those who were there, making pilgrimages or attending services. ${ }^{48}$ Despite such methodological challenges, these interviews offer important perspectives on the intersection of cultural diversity and collective memory.

For Thanh, a 23-year-old who had recently migrated from Vietnam, references to Australian history such as Anzac Day and Australia Day were known and understood, but not felt: 'I choose to live here, which is why I have to know the meaning of Australia Day — why they have the history, and what is the meaning of the Anzac', she explained. 'I know it, and I learn about it, but the connection and the feeling for that, I still don't have it — still have to learn it. ${ }^{49}$ Anu (45 years), of Indian descent, had migrated with her family to Chatswood from London five years earlier. She acknowledged the significance of Anzac Day, but felt disconnected from the 'Anzac story' and uncomfortable with its public focus on Australianness and national identity: 'I feel I have to tread very carefully, so as not to sound unAustralian,' she admitted.

So I try to reinforce to my children, 'Look, it's really important that you respect this occasion', and it is a very, very sad occasion. But coming from India, and my husband comes from Burma, where, you know, people are being killed in their thousands all the time everyday. It doesn't feel that relevant to us, but I use Anzac Day as a springboard to highlight what else is going on, and also, how stuff is reported. ${ }^{50}$

Madihah (39 years), a migrant from Bangladesh, was similarly aware of Anzac's place in the Australian commemorative calendar, but remained more attuned to the history she had grown up with: 'here, like, we are celebrating Harmony Day, we are celebrating Refugee Week, Anzac Day, we are doing so many things ... but still I don't feel like I'm connected', she said. 'But if it is sixteenth December-

\footnotetext{
${ }^{48}$ See for example, Scates, Return to Gallipoli, xviii-xx, and Fathi, 345-59.

${ }^{49}$ Interview with migrant resource centre, Marrickville, 29 June 2011.

${ }^{50}$ Interview with migrant resource centre, Chatswood, 22 October 2010.
} 
Independence Day-I feel more like, even here I feel like it's our Independence Day. ${ }^{, 51}$

Remembering her own mixed feelings on Anzac Day (growing up as a German-speaking child of Jewish refugees), Deborah (64 years) wondered how young migrant children would relate to this national commemoration:

I mean, for me, I think Anzac Day, it's a great story, you know, these Aussies who went over there and got slaughtered. It always makes me feel very emotional, and quite Australian, actually. I get into that. But I also think, you know, it's difficult for people who come from a non-British background. I wonder about, you know, little kids who are Lebanese or Greek or Chinese, how they relate to it. I'm sure they don't relate to it—in the same way I didn't relate to it as a kid. ${ }^{52}$

In fact, the interviews played out Deborah's concerns, bucking the trend of youthful adherence to the Anzac story. Samantha (16 years), of Chinese descent, criticised the centrality given to Anzac Day in public discourse at the expense of an international perspective:

Well, like, it might mean something to Australia, but to be honest with you, Australia's kind of a really insignificant country on a global scale. Maybe it means a lot to us, but many people around the world don't really realize it, because it's like, it might be the biggest thing that happened in World War One for us, but like, there were many other massive events and dates which were like far more significant for others. ${ }^{53}$

And unlike Jed from Chatswood, who had insisted on Anzac Day's significance to his sense of national identity ('like, more than Australia Day'), Jia, a seventeen-year-old Chinese-Australian from the same youth group, was not so sure. What about a day like Anzac Day-does that mean anything to you? Jia, 'I think less than Australia Day, for me, yeah.' 54

For those first or second generation Australians who have no obvious familial connection with Australia's military history, it is understandable that the public narratives of journeying, arrival and multicultural diversity espoused on Australia Day might feel more relevant and substantial. ${ }^{55}$ Yet that disconnectedness from Anzac

\footnotetext{
${ }^{51}$ Interview with migrant resource centre, Marrickville, 29 June 2011.

${ }^{52}$ Interview with Deborah, Chatswood, 14 October 2010.

${ }^{53}$ Interview with Willoughby Youth Action Group, Chatswood, 19 May 2009.

${ }^{54}$ Interview with Willoughby Youth Action Group, Chatswood, 19 May 2009.

55 'Oi! Let's thanks our lucky stars', Gold Coast Bulletin, 26 January 2009, 16; 'Look to the future for an Australia Day date', The Age, 26 January 2009, http://www.theage.com.au/opinion/editorial/look-tothe-future-for-an-australia-day-date-20090126-7pym.html; (accessed 27 January 2009); ‘Australia Day
} 
Day, surely intrinsic to understanding and mapping the dimensions of Australian historical consciousness, has been largely overlooked in scholarship about the Anzac revival. ${ }^{56}$

\section{Anzac as a diverse historical conversation}

Commemorative uncertainty was not restricted to Indigenous and migrant perspectives, as noted above. This research suggests that Anzac commemoration is a complex and multi-valent historical moment for many people in the broader community. Even within the one interview, as this conversation from a bushcare group in Chatswood demonstrated, there could be disagreement about the meaning of Anzac and Anzac Day:

Pru: Fifty years ago in Sydney, Anzac Day was quite a big and quite a solemn deal. I remember working in town-I used to work on public holidays, and we'd watch the march and so on. And then I think it completely died off and it must have been Vietnam, was it, that people stopped glorifying war. And it's only been in the last ten, fifteen years that, I think, the young people and everybody's embraced it so much. It's been a mystery to me. People flocking over to Gallipoli, for goodness sake. And that's only been happening in the last ten, fifteen years, hasn't it?

Amelia: But do you think it's glorifying it?

Pru: Oh yes, I do rather.

Daniel: You don't think it's a celebration of people who've died.

Pru: A tribute? Yes, it's that too. But there's a certain amount of glorification.

Daniel: I've never seen it as a glorification.

Tony: No, I never have either.

Pru: But the kids going to Gallipoli?

Tony: But we visited Gallipoli a few years ago, and I found it a very moving experienceunexpectedly moving actually. And there were young kids from Australia and New Zealand throughout Turkey travelling towards Gallipoli, and I don't think they were going to celebrate

a reminder of all we have to celebrate', The West Australian, 26 January 2009, 20; 'Day to celebrate our way of life', The Canberra Times, 26 January 2009, 8; Edwina Scott, 'Flags of all nations converge at Melb Australia Day parade', Australian Associated Press General News, 26 January 2009. (Sure. Just delete. I tried to google it and couldn't...)

${ }^{56}$ An exception to this is Brown's Anzac's Long Shadow, in which he discusses the mixed feeling among veterans towards the mythologisation of Anzac 
war. I think they were going to have a bit of a party and have a focus for being there, you know.

I think it's quite a nice, sort of, development that young people are embracing. ${ }^{57}$

Not only was there debate among particular interview groups about the meaning and importance of Anzac Day, a number of people I spoke with also admitted that they simultaneously inhabited those margins between intense historical connection and critique. While Nigel (58 years) from Chatswood watched his son march in the Anzac Day parade, the day itself also brought back memories of his wounded grandfather, who 'lost an arm on a charge that was ridiculous in Gallipoli, and as a result suffered the rest of his life'. That family history meant he connected 'with a lot of our history in a very negative way', he admitted. ${ }^{58}$

At a historical society in Rockhampton, Natalie was 'ambivalent' about the occasion, 'because my own father was at Gallipoli', she said. 'So it gives me a real interest, but I don't know. It's hard to explain, but I just don't go to Anzac things any more.' For her, the increasing popularisation of Anzac Day had complicated her own attachment: 'it's probably because back then when I was young, it was a day of commemoration and nothing else. Now it's just become a holiday and it's hard to think about it. ${ }^{59}$ Meanwhile, in Marrickville, Douglas (65 years) also felt connected personally to the day itself but was equivocal about what it had become:

Anzac Day I have some emotional connection to, but I don't celebrate it because I think it's attempting to form a notion of identity around that war...So the reason that I think about Anzac Day is because I did have grandparents in that war and a couple of them killed in that war, so I'm aware of it, and I don't disparage the old diggers celebrating what they did. I just don't think it should be used in that way. ${ }^{60}$

That this ambivalence tended to come more from older participants is no coincidence. Part of the strength of the Anzac resurgence among young people is its temporal distance, which paradoxically enables forms of mythologising that manifest as historical connection and proximity. For those participants whose memories of their veteran relatives were often only a generation away, talking about Anzac Day in the interviews could be fraught. Wrestling with conflicted, contrary thoughts on this most

\footnotetext{
${ }^{57}$ Interview with Bushcare Group, Chatswood, 28 October 2010.

${ }^{58}$ Interview with Men's Shed, Chatswood, 14 October 2010.

${ }^{59}$ Interview with Rockhampton Historical Society, Rockhampton, 28 May 2009.

${ }^{60}$ Interview with Addison Road Community Centre, Marrickville, 9 December 2010.
} 
national of days is not restricted to historians or academics, it seems, bearing out Michelle Arrow's contention that 'the scholarly focus on Anzac Day commemorations and political rhetoric has obscured personal attachments to Australia's military past, which do not always manifest in public commemoration' ${ }^{61}$

Willa from Chatswood reflected on how she had shared that day with her father, a First World War veteran, when she was a little girl: they polished their shoes and medals together, picked the rosemary and set off in the dark to attend the dawn service, which was followed by 'milk and rum', she explained. But she found herself being pulled in different directions as an adult,

I still cry on Anzac Day. I still have a very strong emotional reaction to it, and I usually watch a bit of it on television, but less and less, because all of my history, my personal history with my father is this shared day.... So I have all these physical memories of that day, apart from how I think of it as a mature person. So it's still one of those days that inspires some sort of weird nationalism and emotional response, but intellectually I have another attitude. ${ }^{62}$

Willa's responses to the Anzac commemoration, 'emotional' and 'intellectual' as she described them, confirm the complex subjectivity of Anzac for a number for Australians. As the historian Graham Seal suggests, it is no simple task to disentangle such complex and conflicted responses: 'On this "one day of the year" the public mythology of Anzac and the private, esoteric folklore of the diggers combine, collude and collide'. ${ }^{63}$

Indeed, public and collective commemorations such as Anzac create that experience of 'communitas', or emotional collectivity, as anthropologist Bruce Kapferer writes, because people bring their own sensibilities and connections to the day. The sociologist and historian, Mabel Berezin, similarly describes a 'language of kinship' and a 'community of feeling' to explore the nexus between our own histories and the collective narratives that we may adhere to. ${ }^{64}$ There is a crashing convergence on Anzac Day of collective and personal memory, of public debate and deeply individual emotions. And it is that very subjectivity - such as differences between

\footnotetext{
${ }^{61}$ Arrow, 599.

${ }^{62}$ Interview with Migrant resource centre, Chatswood, 22 October 2010.

${ }^{63}$ Graham Seal, Inventing Anzac: The Digger and National Mythology (Brisbane: University of Queensland Press, 2004).

${ }^{64}$ Bruce Kapferer, Legends of People, Myths of State (New York: Berghahn Books, 2012), 163; Mabel Berezin, 'Secure States: Towards a Political Sociology of Emotion', in Emotions and Sociology, ed., J Barbalet (London: Basil Blackwell, 2002), 35, 42.
} 
participants' social generations or cultural background-which test and complicate assumptions about the extent and impact of the Anzac revival.

\section{Conclusion}

An extraordinary resurgence of military adulation and commemoration has occurred in Australia over the last thirty years. Journeys of pilgrimage, packed dawn services, and substantial Australian government funding for commemorative events suggest Anzac Day is arguably Australia's most significant national day, after being almost moribund a generation ago. ${ }^{65}$ But amid the Anzac cheer, these interviews reveal modulation in its apparent revival; they are grounded examples of commemorative complexity that confirm the enduring dynamism of Anzac, but also unsettle the public narrative of its ascendency in popular historical consciousness. By investigating the depth and diversity of Australians' historical consciousness, this research has uncovered and given voice to commemorative ambivalence and critique in Australian communities. 'If we only look at national commemorations and popular histories in terms of the ways they are deployed in political debate,' as Arrow contends, 'then we are in danger of missing their personal and affective dimensions'. ${ }^{66}$ This qualitative, community-based research does not diminish the historiography on Anzac's increasing centrality in Australian collective memory-it simply suggests the limits of that commemoration need to be unpacked if the impact of its legacy is to be properly understood.

Anna Clark

University of Technology Sydney

Email: anna.clark@uts.edu.au

\footnotetext{
${ }^{65}$ Holbrook, 207-17; Ashton and Hamilton, 47-8.

${ }^{66}$ Arrow, 607.
} 